\title{
RAÇA, MESTIÇAGEM E DEŚIGNAÇÕES SOCIORRACIAIS NO ROMANCE O MULATO, DE ALUÍSIO AZEVEDO (1850-1881)
}

Race, interbreeding and socio-racial designations in the novel O mulato by Aluísio Azevedo (1850-1881) 


\title{
RAÇA, MESTIÇAGEM E DESIGNAÇÕES SOCIORRACIAIS NO ROMANCE O MULATO, DE ALUÍSIO AZEVEDO (1850-1881)
}

\section{RESUMO}

Neste artigo propõe-se uma leitura histórica do romance O mulato (1881), de Aluísio Azevedo. A metodologia adotada é o contextualismo: analisamos a primeira edição do romance em meio ao contexto coevo de discussões entre os periódicos maranhenses O Pensador e Civilização, respectivamente, órgãos de imprensa do círculo intelectual de Aluísio e do clero local. Procuramos demonstrar que Aluísio recorreu a alegorias e representações historiográfico-memorialísticas para construir a semântica sociorracial do romance e dialogou com os intelectuais da sua época, posicionando-se contra as teses de degeneração racial dos mestiços e favoráveis à ideologia do branqueamento racial.

PALAVRAS-CHAVE: Literatura. Raça. Mestiçagem.

\section{RACE, INTERBREEDING AND SOCIO-RACIAL DESIGNATIONS IN THE NOVEL O MULATO BY ALUÍSIO AZEVEDO (1850-1881)}

\begin{abstract}
The article proposes a historical reading of the novel $O$ mulato (1881) by Aluísio Azevedo. The methodology adopted is contextualism: we analyze the first edition of the novel in the midst of the context of discussions between the newspapers $O$ Pensador and Civilização from Maranhão, respectively, press organs of the intellectual circle of Aluísio and the local clergy. We sought to demonstrate that Aluísio used allegories and memorial-historiographical representations to construct the socio-racial semantics of the novel and dialogued with the intellectuals of his time, positioning himself against the theses of racial degeneration of the mestizos and favorably towards the ideology of racial whiteness.

KEYWORDS: Literature. Race. Interbreeding.
\end{abstract}


busca do sentido histórico das transformações ocorridas na sociedade brasileira em romances consagrados de nossa literatura não é recente. A relevância da história para a compreensão de obras-primas de ilustres literatos brasileiros, como Machado de Assis, foi assinalada não apenas por historiadores, mas também pelos críticos literários. ${ }^{1}$

Entre os que aproximaram história e literatura, a pesquisa e a interpretação constituíram o duplo caminho pelo qual tiveram de percorrer. $O$ interesse em desvendar em romances o sentido da experiência histórica de um literato ou de uma sociedade fez com que os estudiosos se voltassem para princípios de inspiração biográfica e psicológica e indagassem sobre o caráter empírico inerente à produção de determinadas obras literárias. Os adeptos dessa vertente analítica buscaram atingir a intencionalidade de um texto através da representação dos motivos recorrentes no seu contexto, fazendo uma ponte entre a personalidade do autor e a obra. ${ }^{2}$ De acordo com essa concepção teórica que enfoca a figura do autor, os romances não são compreendidos enquanto produções desprendidas da realidade social que lhes deu origem. Ao contrário, são vistos como crônicas de um tempo e, em virtude de consistirem em testemunhos históricos, se convertem em documentos para a história social e para a história das ideias.

A proposta de exegese de romances portadores de interpretações sociológicas dos significados mais gerais da vida social de uma época torna-se ainda mais factível quando o tempo e o espaço ficcional coincidem com os do autor. Assim, ao retratar a sociedade na qual está inserido, o autor apresenta ao leitor uma representação da sociedade em que viveu. ${ }^{3}$ Indo do texto ao contexto, ou seja, da narrativa ficcional ao contexto histórico do autor, podemos compreender como tais "leituras" do social foram construídas. Essa verossimilhança entre a ficção do romance e a realidade social do autor é verificável em algumas das páginas mais conhecidas de nossa literatura. $A$ escrava Isaura (1875), por exemplo, pode ser lido como uma denúncia de Bernardo Guimarães dos vícios da escravidão e como um episódio em meio à campanha pela abolição, o que conferiu ao livro a alcunha de "romance abolicionista". Assim, aqueles que se aventuraram pelas searas da história na literatura buscaram nos romances os códigos sociais e as estruturas, sejam elas políticas, sociais ou econômicas, além das tradições e dos costumes, elementos que constituem um quadro mais amplo sob o qual a trama ficcional se desenrola, mas que são alçados ao primeiro plano analítico em uma leitura histórica.

Sem dúvida, podemos afirmar que a produção de uma obra literária possui uma história. Evidentemente, a concepção de autoria, a publicação e a recepção de um escrito por parte do público tem uma história, que pode ser verificada segundo os métodos e as técnicas de pesquisa em história das ideias ou história dos livros e das leituras. A polêmica reside, entretanto, alhures: a busca da história está ao nível do enredo ou da trama literária. Embora a análise do contexto de produção dos romances tenha movido uma vertente analítica da teoria literária no passado, ainda

\footnotetext{
${ }^{1}$ Entre os historiadores, cf. Astrojildo Pereira (1991), Raimundo Faoro (1974), Jefferson Cano (2001) e Sidney Chalhoub (2003). Entre os críticos literários, cf. John Gledson (1986) e Roberto Schwarz (1981; 1990).

2 Sobre as teorias centradas nos autores e nos contextos, cf. SOUZA, 1987, p. 56-124.

${ }^{3}$ Sobre o conceito de representação, cf. CHARTIER, 1990.
} 
se faz presente uma tendência de pesquisa em literatura que é guiada pela análise da obra per si, posição essa que, ao desconsiderar o contexto sociocultural do literato, atravanca os estudos na fronteira entre história e literatura. Segundo essa vertente, os aspectos estéticos e retóricos de um romance devem ser analisados, sob a ótica da crítica literária, como algo que transcende ao tempo, que possui uma "essência". Para esses críticos, "os elementos históricos e sociológicos [num romance, por exemplo, de Machado de Assis] são ricos e abundantes, mas não transpassam um certo nível da narrativa" (CADEMARTORI, 1998). Desse modo, a ficção de literatos da segunda metade do século XIX não estava voltada para a ilustração de fatos históricos, mas o contrário. A nosso ver, essa abordagem é pertinente, mas deixa incultos os campos de pesquisa abertos por uma análise histórica de textos de literatura, entendidos como documento ou crônica histórica.

Polêmicas à parte, a fronteira entre história e literatura tem sido explorada tanto por críticos literários quanto por historiadores. Em nossa análise d'O mulato (1881) de Aluísio Azevedo, adotamos a metodologia de pesquisa de Sidney Chalhoub e de outros pesquisadores do Centro de Pesquisa em História Social da Cultura (CECULT), ${ }^{4}$ que "relaciona texto e contexto". ${ }^{5}$ Acreditamos que, além da leitura dos aspectos estéticos, da narrativa e da retórica de um romance, é possível lê-lo sob o ponto de vista da história social. Nesse sentido, cabe ao historiador ler as primeiras edições desses romances, já que as posteriores podem sofrer "atualizações", e em seus veículos originais de produção. Durante o século XIX, a literatura estava em relação íntima com os periódicos, sendo muitos romances publicados em folhetim. Por esse motivo, o historiador deve ler esses romances nos periódicos em que apareceram originalmente, colocando-os em relação com o que os cercava, com as ideias e crônicas circundantes. Esse método contextualista foi adotado em nossa pesquisa. Mas, para além desse sentido mais circunscrito de contexto, também analisaremos, em sentido mais amplo, as representações que Aluísio Azevedo imprimiu n'O mulato acerca de questões candentes da época, tais como a construção da nação, a mestiçagem e os determinismos raciais e do meio. O recorte cronológico deste artigo abrange os anos entre c.1850 e 1881, respectivamente, época do enredo ficcional e data de publicação da primeira edição da obra. ${ }^{6}$

\footnotetext{
${ }^{4}$ Para uma apreciação dessa vertente de diálogo entre história e literatura, vide, entre outros, Sidney Chalhoub (2005).

${ }^{5}$ Sidney Chalhoub, que se aproximou da obra de Machado de Assis desde Visões da liberdade (1990) e ministrou cursos de história e literatura durante toda a década de 1990 na Universidade Estadual de Campinas, em Machado de Assis, historiador, demonstrou como os romances de Machado de Assis abrem janelas para se compreender como a atividade do literato imiscuía-se à do funcionário do Ministério da Agricultura envolvido com a aplicação da lei do Ventre Livre (1871). O diálogo com a obra de John Gledson e de outros críticos da produção machadiana que aproximaram crítica literária e história foi um dos alicerces da leitura de Chalhoub, bem como o "estofo da história", isto é, um longo lastro de pesquisa sobre a escravidão na segunda metade do século XIX (Cf. CHALHOUB, 2003).

${ }^{6} \mathrm{De}$ acordo com Sidney Chalhoub, a leitura de um romance enquanto testemunho histórico deve apoiar-se sobre duas historicidades: a da obra, ou seja, aquela em que se desenvolve a ficção, e a de sua redação/publicação (CHALHOUB, 2003, p. 18). Existem dois manuscritos autógrafos d'O mulato, datados de 1879-1880. Um deles (uma versão incompleta) encontra-se no Museu Histórico e Artístico de São Luís; o outro está arquivado na sessão de manuscritos da Academia Brasileira de Letras. A primeira edição d'O mulato, publicada em 1881, decorre do segundo manuscrito. Apesar de a segunda edição da obra - publicada em 1889 e significativamente alterada em termos de linguagem - constituir a matriz das edições atuais, preferimos recorrer à primeira edição com o objetivo de historicizá-la,
} 
A primeira parte do artigo é dedicada a uma exposição sobre o modo como os intelectuais brasileiros acomodaram as teorias raciais europeias à realidade brasileira, tendo por objetivo delinear o contexto de debates de ideias mais gerais dos anos 1880, época de publicação do romance analisado. Na segunda parte, ensejando uma breve biografia do autor da obra, apontamos como a atividade de caricaturista permeou a escrita romanesca de Aluísio. A terceira parte discute em que medida o romance de Aluísio se constitui uma fonte histórica, inserindo-o no seu contexto de publicação, ou seja, no conflito entre o periódico fundado em São Luís pelo círculo intelectual de Aluísio e o jornal do clero local. A quarta seção do artigo apresenta e dialoga criticamente com as leituras históricas do romance de Aluísio Azevedo realizadas por Josué Montello e Gilberto Freyre. Na última parte, sondamos as designações sociorraciais usadas por Aluísio no romance, fruto de pesquisas históricas e de representações presentes na sociedade de sua época, e, sobretudo, apresentamos alegorias presentes no romance para tratar do atraso ou modernidade do Brasil e para definir a posição do autor sobre as discussões raciais da época em que viveu. Procuramos demonstrar que $O$ mulato fornece indícios substanciais de que Aluísio se posicionava contrariamente às teses de degeneração racial e moral dos mestiços, refutando determinismos raciais e favorecendo as teses de branqueamento social.

\section{Os intelectuais brasileiros e o "racialismo" na segunda metade do século XIX}

O século XIX testemunhou dois momentos contraditórios no pensamento racial. Por um lado, havia os movimentos abolicionistas, que triunfavam pelo Atlântico Norte e Sul. Por outro, no momento em que a escravidão recuava sob o impacto das transformações econômicas e da sua ilegitimidade moral, pensadores europeus ocupavam-se em sistematizar teorias que versavam sobre as diferenças inatas entre as raças humanas (SKIDMORE, 1976, p. 65).

$\mathrm{Na}$ Europa de meados do Oitocentos, pensadores ingleses, franceses e suíços se ocupavam com a formulação de explicações para o sucesso econômico das mais avançadas nações europeias. A questão fundamental referia-se às razões "científicas" para o êxito do Velho Mundo e, inversamente, para o fracasso de regiões como o Brasil. Concluía-se que "os europeus do norte eram raças 'superiores' e gozavam do clima 'ideal'" (SKIDMORE, 1976, p. 44). Os dois mais conhecidos escritores desse tipo de literatura "científica" foram o historiador inglês Henry Thomas Buckle (18211862), cujos vários volumes de História da civilização na Inglaterra (1857-1861) continham a filosofia do determinismo climático, e o escritor-filósofo francês Arthur de Gobineau (1816-1882), o mais eloquente difusor das teses do determinismo racial. Diferentemente de Buckle, Gobineau veio ao Brasil após a publicação de seu Essai sur l'inegalité des races humaines (1853-1855), passando a identificar o Brasil como "laboratório experimental das suas teorias." Afirmou que o Brasil era "culturalmente estagnado." Gobineau nutria verdadeiro desprezo pelos brasileiros, vendo-os "como irrevogavelmente manchados pela miscigenação" (SKIDMORE, 1976, p. 46-48). Além

inserindo-a no contexto das lutas que o grupo de Aluísio travava com o clero maranhense e, de um modo geral, com as forças reacionárias da sociedade brasileira (CRUZ, 2003, p. 271-272). 
de Buckle e Gobineau, o zoólogo suíço Louis Agassiz também ressaltou a degeneração das raças pela mestiçagem no Brasil, que conheceu em viagem feita em 1865.

A discussão sobre a evolução da espécie humana era, então, balizada pelas teses da biologia, da antropologia e da etnologia, que dividiam os estudiosos em adeptos de versões monogenistas e poligenistas. Para os adeptos da tese de que os homens possuem origens diferentes (poligenistas), a "mestiçagem racial" afigurava-se como um mau: "os mestiços exemplificavam a diferença fundamental entre as raças e personificavam a 'degeneração' que advinha do cruzamento de “espécies diversas'” (SCHWARCZ, 1993, p. 56-57). As ideias do conde de Gobineau, considerado o "inimigo oficial do Brasil", como dito acima, servem de exemplo à condenação da mestiçagem. Como advertiu Lilia Schwarcz, as teses deterministas e racistas tiveram grande aceitação entre os homens de ciência no Brasil de fins do século XIX. As escolas de medicina e direito, os museus etnográficos e os institutos históricos absorveram amplamente essas teorias, não obstante realizassem uma "leitura seletiva" de autores e textos, propalando uma visão sui generis do discurso europeu sobre a raça e a mestiçagem. ${ }^{7}$

\begin{abstract}
O conceito de raça, [...] além de sua definição biológica, acabou recebendo uma interpretação, sobretudo, social. O termo raça, antes de aparecer como um conceito fechado, fixo e natural, é entendido como um objeto de conhecimento, cujo significado estará sendo constantemente renegociado e experimentado nesse contexto histórico específico, que tanto investiu em modelos biológicos de análise (SCHWARCZ, 1993, p. 17).
\end{abstract}

A peculiar acolhida dessas ideias no Brasil das últimas décadas do Oitocentos deve-se, ainda, à arraigada visão do país como melting pot ou cadinho de raças, como assinalou Angela Alonso. ${ }^{8}$ A concepção de "país mestiço", que permeou a literatura científica brasileira no século XIX, deu um tonus específico à receptividade das teorias racistas, que tiveram de ser adequadas a uma nação mestiça e muito distante do suposto arianismo dos países europeus de clima temperado. "Falar da adoção das teorias raciais no Brasil implica pensar sobre um modelo que incorporou o que serviu e esqueceu o que não se ajustava" (SCHWARCZ, 1993, p. 242).

\footnotetext{
${ }^{7}$ Em seu estudo, Lilia Schwarcz tece críticas ao livro de Skidmore, para quem, no período entre 1870 a 1930, teria existido uma protociência brasileira em tudo tributária do pensamento racista e determinista europeu. A autora pretende demonstrar, ao invés disso, que, quando chegou ao Brasil, a "bossa racial" já havia entrado em descrédito na Europa, consistindo numa apropriação tardia dos intelectuais brasileiros. Essa apropriação não foi, de maneira alguma, literal, mas seletiva, tanto no que diz respeito aos textos selecionados, quanto aos autores elegidos para o debate. Como notou Schwarcz, as teorias deterministas de Buckle, Agassiz e do conde de Gobineau, quando aplicadas ao contexto brasileiro, pouca margem davam para um país de raças miscigenadas e com uma natureza exuberante. Desse modo, a apropriação dessas ideias por parte dos intelectuais brasileiros não poderia ocorrer literalmente, mas enviesada e parcialmente (Cf. SCHWARCZ, 1993, p. 41).

${ }^{8}$ Contra a tese de mimese de teorias raciais europeias, defendida por Thomas Skidmore, Alonso argumenta que o ímpeto reformista da geração de 1870 não se deu através de um alheamento ou indiferença com relação à realidade nacional brasileira. Desse modo, o repertório intelectual europeu não foi assimilado integralmente no interior de um "debate intelectual abstrato", mas criteriosamente selecionado "conforme a sua capacidade de elucidar a conjuntura brasileira e oferecer armas para a política” (ALONSO, 2002, p. 332).
} 
A difusão das teorias deterministas e racistas no Brasil das décadas de 1870 e 1880 tornou paradoxal o trato dado pelos abolicionistas à questão racial: embora condenassem a escravidão, agiam com desprezo perante os negros, tidos como racialmente inferiores. Como notou Manuela Carneiro da Cunha, após o "desmantelamento do escravismo e a construção de instituições assentes em uma igualdade política", a hierarquia social encontrou "refúgio e apoio ideológico em um discurso racial. O Brasil, de 1870 a 1930, é assim, a um tempo, liberal e racista" (CUNHA in SCHWARCZ, 1993, p. 9). Lilia Schwarcz assinalou uma convivência bastante extravagante entre o discurso liberal e o racial durante as décadas finais do século XIX: "se o primeiro constará no texto da lei, das falas oficiais, o segundo surgirá nos romances naturalistas, nas teses científicas - seja na área do direito, seja na medicina, nas ciências naturais ou na história" (SCHWARCZ, 1993, p. 245).

A década de 1870, sob o ponto de vista de historiadores mais tradicionais, como Capistrano de Abreu, e de críticos literários mais radicais, como Silvio Romero, consistiu num "divisor de águas". A "década das inovações" anunciava o começo de uma nova era. Os modelos políticos, o ataque à religião, o regime de trabalho, a literatura e as teorias científicas sinalizavam, igualmente, o devir de outra sociedade. "Largamente utilizado pela política imperialista europeia, o discurso evolucionista e determinista penetra no Brasil a partir dos anos 70 como um novo argumento para explicar as diferenças internas" (SCHWARCZ, 1993, p. 28). Além disso, "nota-se a introdução de diferentes teorias de pensamento no cenário intelectual e político brasileiro, tais como o positivismo, o evolucionismo e o darwinismo" (SCHWARCZ, 1993, p. 43). Nesse ínterim, o pensamento abolicionista deve ser compreendido como mais um dos frutos das doutrinas do liberalismo europeu do século XIX.

De acordo com Thomas Skidmore, o ápice do pensamento racial brasileiro amparado cientificamente compreende os anos entre 1880 e 1920, período de vigência do "ideal da branquidade" (SKIDMORE, 1976, p. 63). Não é, porém, correto afirmar que, antes da abolição da escravidão (1888), a maior parcela da elite brasileira "[...] pouca atenção dava ao problema da raça em si, bem como à relação entre as características raciais do país e seu desenvolvimento futuro" (SKIDMORE, 1976, p. 12). Roberto Ventura demonstrou que, desde meados do século XIX, um discurso científico de viés etnológico e naturalista se instaurou no Brasil, de modo que a história e a literatura dos anos 1850 já se pautavam por uma explicação baseada na raça e na natureza, "o que explica a recepção privilegiada de paradigmas de pensamento, como o positivismo, o evolucionismo e o racismo, que adquirem, até primórdios do século $X X$, importância central" (VENTURA, 1987, p. 34). ${ }^{9}$ Assim, quando a oposição à escravatura adquiriu força política no Brasil durante a segunda metade do século XIX, a questão da "raça" já estava posta no debate intelectual brasileiro. Pensadores como Perdigão Malheiro e Joaquim Nabuco bebiam na fonte das teorias raciais e deterministas de intelectuais franceses, mas as suas conclusões sobre o fim da escravidão e o legado racial do negro ao Brasil não caminhavam juntas. Os abolicionistas, em geral, acreditavam no

\footnotetext{
${ }^{9}$ Ademais, como observou Célia Maria Marinho de Azevedo, apesar do termo "racismo" remontar à segunda metade do século XIX, desde os anos 1830 podemos identificar um "antirracismo", já que "a percepção de que o reconhecimento público das 'raças humanas' gerava desigualdades políticas e sociais já encontrava algum poder de expressão na denúncia de 'preconceito de cor' contra os cidadãos afrodescendentes, ditos 'de cor'” (AZEVEDO, 2005, p. 299-300).
} 
"branqueamento", apostando que o Brasil deveria "aprimorar-se" eugenicamente. Em estudo recente, Wlamyra Albuquerque ressaltou que, no processo emancipacionista, se constituíram estratégias de racialização das relações sociais, que embora existentes bem antes dos anos 1880, assumiram novas colorações na década final da escravidão e, sobretudo, após a abolição (ALBUQUERQUE, 2010, p. 99-100).

As opiniões de Silvio Romero (1851-1914), por exemplo, acerca das teorias "racialistas" - para usar o termo empregado por Tzvetan Todorov (1993) -10 foram decantadas entre 1869 e 1881 e resumidas na sua obra-prima História da literatura brasileira, publicada em 1888. Romero, crítico literário que aplicava uma abordagem sociológica à literatura, argumentava que a "raça" e o "meio" eram as chaves para a interpretação da criação artística. Apesar de intitular-se um "darwinista social", Romero pôs reservas ao pensamento de Herbert Spencer e atacou diretamente as leis deterministas do meio de Buckle, que julgava exageradas e demasiadamente "cosmográficas". Romero acreditava que o habitat brasileiro era debilitante, mas preocupava-se mais detidamente com a raça. Corroborando o "mito das três raças" difundido desde, pelo menos, a monografia premiada de Friedrich von Martius entregue ao concurso promovido pelo Instituto Histórico Geográfico Brasileiro (IHGB), "Como se deve escrever a história do Brasil” (1844) -, Romero afirmava que o caráter particular do Brasil advinha da mistura das raças branca, índia e africana. A princípio, Romero adotou a ideia básica de hierarquização racial, embora afirmasse o caráter vago da definição de raça e que as "raças históricas", inclusive a ariana, viviam em constante cruzamento e fundição (SKIDMORE, 1976, p. 50). ${ }^{11}$ Posteriormente, tornou-se um dos pensadores que defenderam a ideologia do "branqueamento", espécie de panacéia para as armadilhas deterministas de Buckle e de Agassiz, que caiu nas graças da elite intelectual após a Proclamação da República, em 1889. A "representação mestiça" que Romero fazia do país funcionava como uma espécie de redenção da nação brasileira. A sua teoria de branqueamento fazia frente à concepção de degeneração das raças cruzadas, que explicava o atraso e a inviabilidade da nação, segundo as teorias racistas (SCHWARCZ, 1993, p. 12-13).

Com efeito, a moda cientificista que ganhava espaço no Brasil da segunda metade do século XIX atingiu os literatos em geral. Como observou Lilia Schwarcz,

[...] os romances naturalistas da época fariam larga utilização e divulgação dos modelos científicos deterministas. Essa é a época em que "a ciência serve de rótulo ao literato", o qual toma mais a exterioridade do pensamento científico a fim de garantir uma suposta "cientificidade literária". [...] A moda cientificista entra no país por meio da literatura e não da ciência mais diretamente. As personagens serão condicionadas pelas máximas deterministas, os enredos terão seu conteúdo determinado pelos princípios de Darwin e Spencer, ou pelas conclusões pessimistas das teorias científicas raciais da época (SCHWARCZ, 1993, p. 32).

\footnotetext{
${ }^{10} \mathrm{O}$ conceito de "racialismo" aplica-se às ideologias ou doutrinas referentes às raças humanas (racistas ou deterministas) que se popularizaram entre os intelectuais europeus entre fins do século XVIII e meados do século XIX, cf. TODOROV, 1993.

11 "O que não impedia de repetir muitas das teorias raciais correntes na Europa sobre a inferioridade racial do índio e do negro" (SKIDMORE, 1976, p. 50).
} 
Portanto, os modelos e as teorias deterministas e racistas foram divulgados, sobretudo, a partir dos heróis e dos enredos da literatura naturalista, "que pareciam guardar mais respeito às máximas científicas evolutivas do que à imaginação do autor" (SCHWARCZ, 1993, p. 32). Assim, uma parcela considerável da literatura brasileira produzida entre 1880 e 1910 é prenhe do cientificismo da época, aclimatado à tropicalidade brasileira, o que nos permite qualificar muitas das obras do período de "romances científicos", verdadeiros "minitratados de fisiologia romanceada" (SCHWARCZ, 1993, p. 32). ${ }^{12}$ Muitos literatos do período conciliavam análises de cunho geográfico com reflexões raciais, concebendo obras cuja principal característica era a busca de regularidades sociais. Os sertões, de Euclides da Cunha, consiste num exemplo ilustrativo da acomodação de modelos das duas escolas deterministas. ${ }^{13}$ Como veremos, Aluísio Azevedo adotou em sua obra o determinismo do meio, refutando as visões fatalistas do determinismo racial - ainda que a racialização não estivesse completamente ausente d'O mulato.

\section{Aluísio Azevedo: de caricaturista a escritor}

Aluísio Tancredo Gonçalves Azevedo nasceu em São Luís a 14 de abril de 1857, filho do vice-cônsul português Davi Gonçalves de Azevedo e de Emília Amália Pinto de Magalhães. Seu pai era viúvo e a mãe divorciada do marido, algo que configurava grande escândalo na sociedade da época.

O jovem Aluísio, fruto desse consórcio, mantinha no seu espírito o gosto pela ciência e pela arte, traço característico de sua personalidade. Desde sua infância, o maranhense revelou forte inclinação para as artes plásticas, notadamente para o desenho e para a pintura. Adolescente, já demonstrava seu talento com a tela e o pincel nas mãos, pintando quadros a óleo. Entusiasmado pelo sucesso que seu irmão mais velho, Arthur Azevedo, obteve na Corte, Aluísio, ainda rapazote, partiu em 1876 para o Rio a fim de matricular-se na Academia Imperial de Belas-Artes. ${ }^{14}$

Chegando à Corte, impossibilitado de realizar a matrícula no curso de artes, dá início a uma bem sucedida carreira de caricaturista. Aluísio Azevedo foi autor de inúmeras charges, contribuindo com as redações de jornais como O Mequetrefe, O Fígaro e Zig-Zag. Sua filiação às causas abolicionista, republicana e anticlerical deixa-se entrever já nesse período, assim como a acidez da crítica social de suas charges, que o levou a conquistar certa notoriedade. Charges como "A propósito dos Trinta Botões" (1876), ${ }^{15}$ publicada no vigésimo número d'O Fígaro, e "As três idades do Brasil" (1877), ${ }^{16}$ publicada na nonagésima quarta edição d'O Mequetrefe, estão

\footnotetext{
12 "No Brasil de finais do século, o racismo científico era moeda corrente. Não se pode afirmar, porém, que o consenso fosse total. Existiram vozes influentes e destoantes, destacando-se os nomes de Manuel Bonfim, Araripe Júnior, Alberto Torres e Joaquim Nabuco. Na literatura, Machado de Assis por várias vezes ironizou esse tipo de teoria, conforme os contos $A$ evolução e $O$ alienista" (SCHWARCZ, 1993, p. 254).

13 "A divisão interna do livro - "A terra", "O homem", "A luta" - bem como o elenco de autores referidos comprovam a influência que esse autor sofreu dos modelos deterministas europeus" (SCHWARCZ, 1993, p. 256).

${ }^{14}$ Sobre a atuação de Arthur Azevedo na imprensa carioca, Cf. Fernando Mencarelli (1999).

${ }^{15}$ O Fígaro, n. 20 - 13/05/1876. Acervo digital da Biblioteca Nacional.

${ }^{16}$ O Mequetrefe, n. 94 - 19/03/1877. Acervo digital da Biblioteca Nacional.
} 
repletas de alegorias que valorizam o elemento indígena em detrimento do português. Na segunda charge, uma "época de ouro" pré-cabralina se opõe à "civilização" (idade de ferro) criada pelos portugueses, caracterizada pelo vício, e a uma "idade de bronze" relacionada à independência, definida como uma farsa. Um homem desengonçado, representando o Brasil em 1877, tem os copos em cada uma das suas mãos servidos pelo Estado (representado por uma prostituta jovem apenas vestida de um crucifixo) e pela Igreja (caricaturada na figura do cônego José Gonçalves Ferreira, diretor do influente periódico católico O Apóstolo).

Apesar de o sucesso de Aluísio como caricaturista no Rio de Janeiro, a morte de seu pai o leva de volta à terra natal. ${ }^{17} \mathrm{Em}$ São Luís, Aluísio Azevedo empregou-se novamente na imprensa, escrevendo crônicas e comentários, ao mesmo tempo em que terminava um romance que iniciou ainda no Rio de Janeiro, Uma lágrima de mulher (1879). Considerado pelos críticos um livro romântico no mais característico estilo piegas, a obra ainda não havia revelado o naturalista de $O$ mulato, Casa de pensão e $O$ cortiço (VERÍSSIMO, 1954, p. 294). No entanto, por esse tempo, o "jovem combativo" se entregava de corpo e alma a uma entrincheirada luta com o clero maranhense, afundado em escândalos..$^{18}$ Suas armas, agora, eram as palavras - e não as imagens. Não obstante, como procuraremos demonstrar à frente, a construção de alegorias e de personagens caricaturadas não foi abandonada por Aluísio em seus romances. As personagens de O mulato, sobretudo, o padre Diogo, Maria Bárbara (avó de Ana Rosa) e o mulato Raimundo são caricatas. A verve de cartunista se imiscuiu, portanto, com a atividade literária de Aluísio, que possuía grande poder na construção de alegorias e em caricaturar os protagonistas de seus romances.

O crítico literário Josué Montello, consultando o acervo de jornais antigos do Maranhão na Biblioteca Pública de São Luís e a coleção particular do historiador José Ribeiro do Amaral, assinalou o surgimento, em setembro de 1880, de um periódico trimensal na capital maranhense. Autointitulado "órgão dos interesses da sociedade moderna", O Pensador reunia atrás de pseudônimos como Marquês de Pombal, Diderot, Pietro Garibaldino, Sóror Pompadour, Marius e Vanini, dentre outros contribuintes, Aluísio Azevedo. Logo no primeiro número, o periódico torna patente seu combate ao "espírito sacerdotal". Além do anticlericalismo, o jornal tinha uma veia cientificista - haja vista a influência do positivismo de Auguste Comte sobre os jovens redatores -, opondo a fé à razão (MONTELLO, 1975, p. 5-6).

Durante os anos que se seguiram até a publicação de $O$ mulato, uma renhida briga fora travada no âmbito da imprensa entre $O$ Pensador e o clero maranhense. Em sua luta pela moralização do clero, o bispo maranhense Dom Antônio Cândido de Alvarenga não restringiu sua ação doutrinária à aplicação de castigos e expulsões, criando também um órgão de imprensa para combater a frouxidão da fé e a licenciosidade dos costumes, chamado Civilização. Os redatores dos dois periódicos trocaram insultos entre 1879 e 1881, chegando ao ponto de citar nomes e de dedicar várias linhas ao escárnio do opositor e ao rebate de críticas. O estudo de Josué Monteiro da polêmica em torno de O mulato é uma importante síntese desta batalha,

\footnotetext{
17 Para uma biografia de Aluísio Azevedo, Cf. Josué Montello (1975).

18 Outros literatos relataram o relaxamento do clero maranhense. Graça Aranha, em 1931, n'O meu próprio romance, por exemplo, faz referência à luta do então novo bispo Dom Antônio "contra o relaxado clero, afundado na sodomia" (ARANHA Apud MONTELLO, 1975, p. 6).
} 
que, como procura demonstrar o crítico literário, atingiu um dos seus pontos mais tensos após a publicação e a difusão do romance. Sob essa óptica, o livro de Azevedo, mais que uma fonte, teria sido um episódio da luta pela destruição de instituições tradicionais brasileiras - a Igreja e a escravidão -, nocivas e arcaicas aos olhos do cientificismo positivista. O livro, contudo, observa Montello, não se esgota na crítica a essas instituições. Para além da denúncia do preconceito de cor e da má vida do clero maranhense, "O Mulato se engrandece como o romance de uma cidade" (MONTELLO, 1975, p. 5). Desse modo, ao desenvolver a trama do romance, Aluísio Azevedo pinta um quadro da sociedade maranhense das últimas décadas da escravidão, desnudando os vícios torpes escondidos pelas batinas e a perenidade de valores ligados à pureza de sangue; enfim, todo um orbe de costumes e tradições provincianas. Portanto, por estar profundamente enraizado nos embates com o clero e, em geral, com as "forças arcaizantes do passado", o romance se radica densamente na história da época: tanto em escala micro, da história local e das relações interpessoais na capital maranhense; quanto em escala macro, ou seja, nacional, em diálogo com as questões então cruciais para a formação da nação.

Cabe destacar que, no tocante às nossas preocupações, a abordagem de Montello serviu de inspiração para o inquérito histórico d'O mulato que faremos a seguir. Entretanto, para além do cientificismo positivista, que se difundiu no Brasil a partir das décadas de 1870 e 1880, procuraremos demonstrar que, embora enfatize a influência do meio e do clima, Aluísio Azevedo historicizou designações raciais anteriores à época da publicação do romance (1881) e dialogou - consciente e inconscientemente - com o "racismo científico" da sua época.

\section{0 romance naturalista como fonte para a história: o caso d'O Mulato}

Considerado o primeiro literato brasileiro a viver exclusivamente de sua arte, Aluísio Azevedo tem sua obra comumente dividida em duas séries distintas: a primeira inclui os romances que resultaram de sua "realização artística" e, a segunda, os que foram concebidos em virtude das suas obrigações de folhetinista. Como a literatura do século XIX era geralmente publicada em folhetins, parece inadequado esse meio de atribuir valor artístico a obras da época. O próprio Machado de Assis publicou em folhetins algumas de suas obras mais importantes, como Memórias póstumas de Brás Cubas e Quincas Borba. Seja como for, as obras-primas de Aluísio - O mulato, Casa de pensão e O cortiço -, enquadram-se na primeira série de romances (MONTELLO, 1975, p. 9). ${ }^{19}$ O primeiro deles foi escrito, provavelmente, em 1880, sendo publicado apenas no ano seguinte, pois, como revelou o seu autor, em 1889, "o volume levou um ano a ser impresso" (AZEVEDO, 1975, p. 18). Apesar de não ter sido publicado como folhetim, O mulato marcou presença n'O Pensador, periódico que Aluísio ajudou a fundar no Maranhão. A edição de 10 de abril de 1881 noticiou a publicação do romance, apontando o próprio escritório do periódico, na Rua da

\footnotetext{
${ }^{19}$ Angela Maria Rubel Fanini (2003), empreendendo uma releitura dos romances-folhetins de Aluísio Azevedo, relativiza a visão que os desqualifica como subliteratura. A autora justifica a linguagem híbrida entre o romantismo e o real-naturalismo presente nessas obras por meio de uma abordagem que articula forma literária e realidade sócio-histórica.
} 
Palma, em São Luís, como local de venda. Os editores, ao mesmo tempo em que ressaltavam o caráter real-naturalista da obra, aproveitavam para atacar o clero local: "Quem quiser conhecer o cônego Diogo [um dos personagens principais d'O mulato], aquele tratante que tanto se parece com João Gadelhudo, agora é a ocasião". ${ }^{20} \mathrm{O}$ viés anticlerical do romance já havia sido anunciado pelo Pensador antes mesmo de sua publicação: "O Mulato. Com este título será no princípio do mês vindouro publicado um romance do Sr. Aluísio Azevedo, no qual o autor propõe-se argumentar abusos religiosos, que se dão nesta cidade". ${ }^{21}$

A publicação do romance gerou críticas instantâneas do periódico opositor ao Pensador. A esperada crítica da Civilização veio no número de 23 de julho de 1881. A crítica, atribuída ao padre Raimundo Alves da Fonseca, foi reproduzida na edição de 30 de julho de 1881 d'O Pensador. A estratégia do padre consistiu em refutar a qualidade artística da obra, mais do que o seu conteúdo. Embora críticas tenham sido feitas ao conteúdo, inclusive à conduta do protagonista do romance (o Dr. Raimundo), a estratégia foi ridicularizar a tentativa de Aluísio de aclimatar o real-naturalismo ao Brasil. Para os críticos da Civilização, "O Mulato é um trabalhosinho alambicado, servil imitação estrangeira; e em certos pontos, miseravelmente plagiado". O mesmo padre que resenhou a obra afirmou que Aluísio arquitetou seu romance sob impressões de leituras de Eça de Queirós, assim como de "amadores da literatura decamerônica." Afirmou que, em Portugal, Bento Moreno possuía sobre o realismo uma compreensão mais consciente e científica do que Eça de Queirós. Por fim, o padre em meio a uma lista infindável de insultos, aconselhou: "À lavoura, meu estúpido! À lavoura! Precisamos de braços e não de prosas em romances! Isto sim é real". ${ }^{22}$

Em 1888, Araripe Júnior, no artigo "Estilo tropical: a fórmula do naturalismo brasileiro", apresentou tese oposta a vista acima. Na visão de Araripe Jr., a adaptação do romance naturalista no Brasil se deu através da "teoria da natureza", substanciada na ideia de "tropicalidade". Era isso, justamente, o que explicava a originalidade do naturalismo de Aluísio Azevedo, que Araripe Jr. definia como o resultado do impacto do meio local sobre as formas e os modelos importados. Portanto, longe de ser plágio ou imitação estrangeira, O mulato e as demais obras naturalistas de Aluísio se caracterizavam pela aclimatação de Émile Zola ao Brasil. A natureza tropical e o clima quente do Brasil obrigavam o escritor naturalista a transformar o "estilo" europeu, abandonando a "correção" e adotando uma escrita repleta de "emoção, nervosidade e sensualismo" (JÚNIOR, 1978, p. 75-76).

Apesar da péssima recepção que o romance recebeu em sua cidade natal, afirmou Aluísio, "a imprensa da corte recebeu-me bem, e, à imitação dela, a de todas as províncias do Norte e do Sul” (AZEVEDO, 1975, p. 19). A edição de 10 de setembro de 1881 d'O Pensador anunciou a partida de Aluísio para o Rio de Janeiro. Sob os lamentos de seus amigos editores no Maranhão, ${ }^{23}$ Aluísio partiu para a Corte, onde foi

\footnotetext{
${ }^{20}$ O Pensador: órgão dos interesses da sociedade moderna (MA), ano 1881, edição 21 (2), Hemeroteca digital, Biblioteca Nacional.

21 O Pensador: órgão dos interesses da sociedade moderna (MA), ano 1881, edição 13 (1), Hemeroteca digital, Biblioteca Nacional.

${ }^{22}$ O Pensador: órgão dos interesses da sociedade moderna (MA), ano 1881, edição 32 (1), Hemeroteca digital, Biblioteca Nacional.

${ }^{23}$ A edição de 10 de setembro de 1881 d'O Pensador anunciou melancolicamente a partida de Aluísio, o "simpático e talentoso cronista". Os companheiros, ao mesmo tempo em que festejavam a sua "verve
} 
amparado pelo acolhimento do supracitado Araripe Júnior e de homens como Sílvio Romero, Capistrano de Abreu, Raul Pompéia e José do Patrocínio.

Assim como outros adeptos do real-naturalismo, ao denunciar os costumes e as tradições provincianas de São Luís do Maranhão, Aluísio realizou um estudo filológico, procurando reproduzir no romance "expressões", "termos", "dizeres e locuções", que Ihe conferem grande importância como registro da língua falada naquela província. Em 1889, ao prefaciar a $2^{a}$ edição de $O$ mulato, Aluísio Azevedo afirmou que empregou

[...] religiosamente, certos dizeres e locuções, que se usam naquela província, posto que os leitores cá do Sul hajam de estranhá-los, como sucedeu com o ilustre falecido Batista Caetano, que, num volume, levado à Biblioteca Nacional pelo meu amigo Capistrano de Abreu, me censurou, à margem de algumas páginas, o uso de muitos termos que ele não conhecia e outros que supunha imitados dos romances portugueses (AZEVEDO, 1975, p. 18).

Contra a acusação, Aluísio teceu a seguinte réplica:

Nosso filólogo ignorava que em São Luís do Maranhão são frequentes certas expressões à moda de Portugal, e aquilo, pois, que se lhe afigurou macaqueado de $C$. Castelo Branco, era simplesmente copiado do natural (AZEVEDO, 1975, p. 18).

Em sua resposta, o literato maranhense torna patente sua intenção de transportar com fidelidade para as linhas do romance de 1881 a língua, tal como era falada em sua província. A aproximação do literato com a filologia levou-o a constatar que, em São Luís, se "empregam palavras de todo desconhecidas no resto do Brasil [...] (e mesmo) em Portugal, mas que por lá, na (sua) província, são muito comuns" (AZEVEDO, 1975, p. 18).

Ademais, a relação de amizade com Capistrano de Abreu pode ter rendido debates sobre aspectos da história do Maranhão - e do Brasil como um todo presentes no romance. Pelos idos de 1881, conforme relatou o literato no prefácio para a $2^{\mathrm{a}}$ edição do romance, um volume foi levado por seu amigo historiador à Biblioteca Nacional. É possível que Aluísio Azevedo tenha procedido dessa forma, visando colocar sua obra à disposição de especialistas diversos que frequentavam o local para pesquisar, pois, segundo carta enviada por Capistrano de Abreu a seu amigo Rio Branco, era lá que o historiador "passava seis horas por dia, estudando, pesquisando, mergulhado em manuscritos" do Conselho Ultramarino, quando seus Capítulos de história colonial ainda engatinhavam (RODRIGUES, 2000, p. 3). Nesse sentido, a discussão do literato maranhense com o filólogo Batista Caetano, mencionada anteriormente, parece corroborar essa conjetura. Portanto, não é descabida a hipótese de que - além das imagens e representações sobre a "raça", de que Aluísio estava imbuído enquanto homem que viveu naquela época -, é possível que o literato tenha

fina e aguçada" (que fazia "o terror dos padres" locais), assinalavam o "vácuo que deixa n'O Pensador, difícil de preencher." O Pensador: órgão dos interesses da sociedade moderna (MA), ano 1881, edição, 36 (3), Hemeroteca digital, Biblioteca Nacional. 
se aproximado da história para retratar aspectos das relações raciais (e sentidos de categorias sociorraciais) durante a época colonial e a primeira metade do século XIX, os quais integraram a sua narrativa romanesca - como procuraremos demonstrar mais adiante.

O livro de Aluísio conta a história do Dr. Raimundo, "o mulato", protagonista do romance. Filho de um tratadista de escravos, o português José, com sua escrava Domingas, o mulato foi alforriado na pia batismal e, na adolescência, enviado para Lisboa e, depois, para Coimbra a fim de tornar-se bacharel em Direito. Ao retornar ao Maranhão, pelos idos de 1850, em ocasião da morte de seu pai, Raimundo instala-se na casa de seu tio paterno, o comerciante português Manuel Pescada, despertando um grande amor em Ana Rosa, filha do comerciante. A família da moça, dotada de grande "preconceito de cor" (AZEVEDO, 1975, p. 194), ao tomar consciência da situação, se posta, de forma resoluta, contrariamente à união, sobretudo a avó da moça. ${ }^{24}$ A mão de Ana Rosa, a exemplo do costume da época, estava reservada ao caixeiro português mais velho da casa comercial de Manuel Pescada, o Dias. Ana Rosa, contudo, fazendo mau juízo do contrato nupcial, e lembrando-se do conselho dado por sua falecida mãe, de que deveria casar com quem desejasse sob pena de ser infeliz pelo resto de seus dias, decide lutar contra os preceitos de branquidade de sua família para desfrutar do amor do mulato, o seu "Mundico". O desfecho do romance, prenhe do fatalismo característico das obras real-naturalistas, culmina com a morte do Dr. Raimundo e o casamento de Ana Rosa com Dias.

O grande crápula do livro é o padre Diogo, religioso relaxado, concubino e assassino. Caricaturalmente construída, a figura do religioso desenhada pela pena de Azevedo exagerou os seus traços maléficos: saiu da arma de Diogo o tiro que matou José, o pai de Raimundo, e foi sob sua influência que o caixeiro Dias resolveu assassinar o mulato. A denúncia da torpeza dos vícios e da hipocrisia sacerdotal, bem como a insistência na influência nociva dos religiosos na sociabilidade de São Luís está em plena consonância com o anticlericalismo de $O$ Pensador, periódico em que Aluísio escrevia crônicas à época em que concebeu $O$ mulato. O romance de 1881, porém, não se resume a mais um episódio da luta travada na imprensa por jovens abolicionistas, anticlericalistas e positivistas reunidos na redação d'O Pensador, consistindo, ainda, num importante "retrato sociológico" da provinciana São Luís.

Certamente, a relevância de $O$ mulato de Aluísio Azevedo enquanto registro da sociedade maranhense das últimas décadas da escravidão deve-se, sobretudo, ao fato de ser uma obra naturalista. O "cientificismo do tempo" observado na obra naturalista de Aluísio advinha da influência das teorias das ciências experimentais da época,

\footnotetext{
${ }^{24}$ Muito afeita à pureza do sangue português que Ihe corria as veias, a avó de Ana Rosa, diante do anseio da moça em casar-se com um mulato, esbravejou: "Pois olha, se tivesse de assistir ao teu casamento com um cabra, juro-te, por esta luz que está nos alumiando, que te preferia uma boa morte, minha neta! Porque serias a primeira que na família sujava o sangue!" (AZEVEDO, 1975, p. 165). Dirigindo-se, dessa vez, ao pai da moça, disse: "Mas creia, seu Manuel, que, se tamanha desgraça viesse a suceder, só a você a deveríamos, porque, no fim das contas, a quem lembra meter em casa um cabra tão cheio de fumaças como o tal doutor das dúzias?... Eles hoje em dia são todos assim!... Dá-se-lhes o pé e tomam a mão!... Já não conhecem o seu lugar, tratantes! Ah, meu tempo! Meu tempo! Que não era preciso estar cá com discussões e políticas! Fez-se besta? Rua! A porta da rua é a serventia da casa! E é o que você deve fazer, seu Manuel! Não seja pamonha! Despeça-o por uma vez para o Sul, com todos os diabos do inferno! E trate de casar sua filha com um branco como ela. Arre!" (AZEVEDO, 1975, p. 165).
} 
que compreendiam o homem como um resultado da pressão do ambiente social. No que tange à leitura do romance como documento histórico, o comprometimento do autor naturalista com a observação do meio - que apresenta os fatos sociais que constituem a matéria-prima para os seus romances - interessa menos pela crença que os movia a supostamente descrever objetivamente a realidade, mas antes por ser a própria realidade o objeto de sua escrita. Portanto, não tomaremos $O$ mulato como uma representação objetiva da realidade social do Maranhão na segunda metade do século XIX, mas como uma leitura enviesada de Aluísio Azevedo, balizada pelas suas apropriações do racismo científico da época. A obra naturalista do mestre maranhense, por esse motivo, "converte-se em documento, sem perder, contudo, o seu valor no plano da criação estética” (MONTELLO, 1963, p. 11). Sobre o romance, afirma Josué Montello,

[...] o preconceito de cor, muito apurado na sociedade maranhense do século XIX, tem no livro de Aluísio a sua exata fixação, em termos de narrativa romanesca. E pode ser transferido da obra literária para o estudo sociológico, a exemplo do que fez Gilberto Freyre (MONTELLO, 1963, p. 12).

Embora $O$ mulato já tenha recebido atenção de muitos outros sociólogos, historiadores ${ }^{25}$ e, sobretudo críticos literários após Montello e Freyre, a exposição seguinte se voltará à obra desses dois autores para apontar formas possíveis de leitura do romance na porosa fronteira entre história e literatura.

\section{Gilberto Freyre e Josué Montello: olhares de sociólogos e críticos literários sobre $\mathbf{O}$ mulato}

Gilberto Freyre, que antecipou postulados da nova história francesa, lançou mão de variadas fontes para a sua interpretação do Brasil, dentre as quais, a literária (BURKE, 1997, p. 4). Em Sobrados e mucambos, no capítulo XI, intitulado "Ascensão do bacharel e do mulato", Freyre recorre a O mulato como fonte histórica da Província do Maranhão. Porém, é na construção do tipo "eugênico" ou "eutênico" do mulato que reside a maior importância do romance de Aluísio Azevedo, na visão de Freyre.

O escritor de Casa-grande \& senzala, divulgador pioneiro da antropologia cultural no Brasil da década de 1930, propalava já, nesse período, uma interpretação do processo de formação de nossa sociedade que recusava as teorias raciais então em voga. ${ }^{26}$ Longe de consistir em um problema, para Freyre, o amalgamento de raças e culturas teria sido, na verdade, o principal legado da colonização dos portugueses, povo mestiço de mouro e africano portador do que chamou de "plasticidade", "adaptabilidade" ou "miscibilidade". É, contudo, em Sobrados e mucambos, que Freyre

\footnotetext{
${ }^{25}$ À guisa de exemplo, citamos Leonardo Affonso de Miranda Pereira (2009).

${ }^{26}$ Durante sua estadia na Universidade de Columbia, Gilberto Freyre foi orientado pelo fundador da antropologia cultural norte-americana, Franz-Boas. A influência da antropologia boasiana na obra de Freyre pode ser observada no uso do conceito de "cultura" (em detrimento do de "raça") e no combate ao evolucionismo biológico-racial (REIS, 2006; DAMATTA in FREYRE, 2006, p. 11-26).
} 
vai além, elogiando de sobeja as características físicas do mulato. ${ }^{27}$ Segundo o escritor, "o híbrido, quando eugênico, parece possuir como nenhum indivíduo de raça pura [...] encanto particular" (FREYRE, 2006, p. 712, grifo nosso). Se, no estudo anterior, Freyre conteve-se em salientar as virtudes de uma cultura híbrida, na tese sobre a decadência do patriarcado rural e a formação do urbano, afirmou que o cruzamento biológico entre portugueses e africanos, quando levava ao aperfeiçoamento genético, resultava em "mestiços ou mulatos claros [...] com a mão pequena, o pé bonito, às vezes os lábios ou o nariz, dos pais fidalgos" (FREYRE, 2006, p. 712). Desse modo, o "mulato eugênico" de Freyre pode ser entendido como uma resposta às teses de imperfeição e degeneração física dos mestiços. Em sua perspectiva, a valoração tradicional do pensamento social brasileiro acerca da eugenia é invertida: ao invés do arianismo das teorias raciais remanescentes do Oitocentos e que ainda calavam fundo ao tempo da concepção de Casa-grande \& senzala, observa-se o hibridismo como um elemento propício à reprodução e ao melhoramento da "raça brasileira".

O mulato, tipo biológico sui generis da "primeira civilização moderna dos trópicos", ora "pela beleza física e pela atração sexual exercida sobre o branco do sexo oposto" ora pelos "atrativos intelectuais" ganhos na Europa ou em educandários e seminários brasileiros, logrou ascender socialmente no século XIX (FREYRE, 2006, p. 732). É certo, que o orgulho de raça, decorrente das concepções europeias de pureza de sangue da época colonial ainda vigentes no imaginário social brasileiro, balizou, em grande medida, a ascensão social das proles resultantes de relações sexuais entre brancos e negros, principalmente, durante as primeiras décadas do Oitocentos. No entanto, como observou Freyre, esse quadro sofreu alterações a partir do quarto decênio do século XIX.

Conforme argumenta o autor de Sobrados e mucambos, o Brasil oitocentista apresentava "[...] duas grandes forças, novas e triunfantes, às vezes reunidas numa só: o bacharel e o mulato" (FREYRE, 2006, p. 711). Contudo, nas primeiras décadas do século XIX, ainda verificava-se a conhecida predileção dos proprietários rurais dos lugares mais afastados em encomendar, aos correspondentes, caixeiros brancos e que soubessem ler e fazer contas. Predileção, aliás, que se manteve firme durante toda a centúria, principalmente nas regiões mais provincianas. Por outro lado, com o Império, sobretudo no reinado de D. Pedro II, o lado "sociológico" que envolvia a contratação de caixeiros passou, paulatinamente, a pesar mais que o "biológico" este último preceito, útil "à economia patriarcal e à pureza de raça das famílias de engenho", mas não ao patriarcado urbano, menos receoso em relação à questão do "sangue rigorosamente limpo". "Saliente-se, entretanto", ressalva Freyre, "que a ascensão social do bacharel, quando mulato evidente, só raramente ocorreu de modo menos dramático" (FREYRE, 2006, p. 723).

\footnotetext{
${ }^{27}$ Curiosamente, ao tratar da mestiçagem, Gilberto Freyre travou uma discussão com tendências antropológicas que ressaltavam a assimetria do mestiço. Esse fato reforça a tese defendida por Jessé Sousa de que o escritor pernambucano não desvincilhara-se por completo do conceito de raça, apesar de seu enfoque notadamente culturalista (SOUZA, 2000). Ademais, como salientou Ricardo Benzaquen de Araújo (1994), em Freyre, a natureza instável do mestiço resulta de uma convivência entre antagonismo culturais e raciais e, não de uma síntese desses elementos, como na visão de Mário de Andrade. Ao que parece, essa tendência, que é observada em Casa-grande \& senzala, ficou mais clara em Sobrados e mucambos. Sobre o assunto, ver o debate que Freyre realizou com as teorias de assimetria dos mestiços sustentadas por Davenport (FREYRE, 2006, p. 735).
} 
A "nova mística" do moço - às vezes, mulato - bem nascido e intelectual sistematizou-se durante o reinado de D. Pedro II, "destruindo quase de todo a antiga: a do capitão-mor velho" (FREYRE, 2006, p. 713). Essa transformação teria sido impulsionada pela decadência do patriarcado rural e pelo desenvolvimento urbano, que criou campo para uma intervenção mais direta do letrado ou do clérigo na política. Ademais, deve-se ainda a essa transformação o advento do "homem fino da cidade" e "a ascensão do brasileiro nato e até do mulato aos cargos públicos e à aristocracia da toga" (FREYRE, 2006, p. 714). Assim, teriam sido estes "bacharéis, doutores e semidoutores de cor" os responsáveis pela formação de uma nova espécie de aristocracia "mais indiferente que as outras à pureza de sangue" (FREYRE, 2006, p. 719). ${ }^{28}$

No tocante ao assunto aqui debatido, o mulato bacharel "fino, eugênico e asseado" descrito em Sobrados e mucambos encontra o seu mais perfeito correspondente na figura do protagonista do romance de 1881 de Aluísio Azevedo, o Dr. Raimundo. Nas palavras de Gilberto Freyre,

\begin{abstract}
AluísioAzevedo deixou-nos em romance-verdadeiro "documento humano" recortado da vida provinciana do seu tempo, segundo a técnica realista que foi um dos primeiros a seguir entre nós - meticuloso retrato de bacharel mulato educado na Europa (FREYRE, 2006, p. 732).
\end{abstract}

Ao traçar o "perfil antropológico do mulato eugênico", Gilberto Freyre recorreu à tradição oral, afirmando que o "mulatão bonito", o Dr. Raimundo do romance, não foi inventado por Aluísio Azevedo, mas "fotografado do vivo, quase sem retoques, segundo o seu método e o da sua escola" (FREYRE, 2006, p. 734). Vê-se que o escritor pernambucano discorda duplamente de Josué Montello, teórico literário que estudou $O$ mulato: por um lado, Freyre ressaltou a intenção de Aluísio de empregar as "técnicas realistas" de Zola, visando um retrato fiel da sociedade maranhense e, por outro, realizou uma leitura das características físicas do herói do romance como testemunho dos fenótipos "eugênicos" do mulato, e não como um resquício de tradições românticas ainda presentes no romance, como acreditava Montello (1975, p. 27).

Freyre aventa, ainda, uma hipótese para a recusa de Manuel Pescada em conceder a mão de sua filha ao Dr. Raimundo: em sua visão, não fora tanto a raça que determinou o impedimento, mas o fato do mulato ser "filho de escrava, negra de engenho, negra que ainda vivia, embora maluca, mulambenta, vagando pelo mato" (FREYRE, 2006, p. 733). Assim, apesar do mulato retratado no romance conjugar elementos essenciais para o "embranquecimento" social - tais como um pai português e rico, o título de bacharel e suas qualidades eugênicas -, o fato de ter sido alforriado à pia, ou seja, ter nascido de ventre escravo, teria sido determinante. Logo, para o escritor pernambucano, a herança do cativeiro transmitida pelo sangue materno, e não propriamente a pele escura, consistia no principal obstáculo para a aceitação dos homens "de cor" na sociedade brasileira, durante a segunda metade do século XIX.

\footnotetext{
${ }^{28}$ Gilberto Freyre (2006, p. 771) evoca a si o título de progenitor da ideia, esboçada em 1936, de que "influem sobre o status do brasileiro menos a raça do que a classe e a região". O escritor pernambucano reconhece, todavia, que Debret, Koster e Rugendas Ihe anteciparam.
} 


\title{
Raça, mestiçagem e categorias sociorraciais n'O mulato (c.1850-1881)
}

\begin{abstract}
Não creio que os latinos sejam condenados a declinar por causa do sangue que corre em suas veias, isto é, em virtude de uma causa fatal, fatal porque um povo não pode mudar de natureza, nem modificar sua constituição física; mas, da história e principalmente dos acontecimentos contemporâneos, parece resultar que os povos católicos progridem muito menos depressa que as nações que deixaram o catolicismo e que, relativamente a estas, parecem recuar (LAVELEYE, 1881).
\end{abstract}

A epígrafe acima, retirada de um artigo publicado n'O Pensador de 30 de novembro de 1881, indica o ponto de vista do círculo intelectual de Aluísio Azevedo acerca das teses de determinismo racial e climático, que vigoravam naquela época. Em correspondência com o editorial do periódico, Aluísio não deu grande ênfase sobre a questão racial n'O mulato. Apesar da denúncia do preconceito de cor existente na capital maranhense da última década da escravidão, é a questão climática e do meio sociocultural de São Luís que explicam o seu atraso, o seu caráter antimoderno, no romance. A ponta-de-lança desse atraso é, n'O mulato como no editorial d'O Pensador, sem dúvida, a Igreja. Apesar da discussão racial não permear o livro, procuraremos demonstrar que Aluísio se valeu de memórias e estudos históricos para embasar o emprego, pelos personagens do romance, de termos raciais do Brasil colonial e imperial. Para além desse emprego terminológico deliberado, também atentaremos à construção de alegorias sobre o Brasil, que encarnam de forma caricaturesca os principais personagens do livro. E no interior de uma perspectiva de uma história estruturante, mesmo não sendo a raça o tema central do livro naturalista em análise, assinalaremos abordagens racialistas, não precisamente intencionais, que brotaram da pena de Aluísio.

Como na charge "As três idades do Brasil" (1877), mencionada anteriormente, n'O mulato, Aluísio procurou criar alegorias assentes na periodização da história do Brasil. O atraso colonial, que ainda se mantinha em São Luís, encarna a Igreja (na figura do padre Diogo), as velhas beatas preconceituosas (como Ana Bárbara, avó de Ana Rosa) e, em certa medida, o insosso caixeiro português Dias. O progresso é representado pelo personagem que vêm de fora, pelo bacharel em Direito formado na Europa, o Dr. Raimundo. A alegoria montada por Aluísio, com base na teoria do determinismo do meio, é a de que o progresso deve vir de alhures, das modernizações europeias, e deve desbancar o atraso colonial ainda em vigor, representado pela influência nefasta da Igreja. O fato de o progresso encarnar um mulato, nascido de um ventre escravo, sugere a adesão de Aluísio ao ideal de branqueamento social e uma valorização da mestiçagem (inclusive, em seus aspectos fenotípicos, como apontou Freyre), na contramão do racismo científico defendido por Nina Rodrigues a partir dos anos 1890.

Para além desse enquadramento geral da obra, na linha interpretativa de Sidney Chalhoub, acreditamos que, ao tratar em O mulato das alterações e acréscimos semânticos que o conceito de raça sofreu entre o período colonial e a segunda metade do século XIX, Aluísio procedeu como um historiador. Isso porque Aluísio convida - leitor a imaginar como alguém de formação colonial pensava as relações raciais entre fins do século XVIII e a primeira metade do século XIX; também por buscar 
"no natural" (ou seja, na realidade social da sua época) as imagens que a sociedade maranhense produzia sobre o seu próprio passado. Não sabemos se as conversas com Capistrano de Abreu ou as tardes na Biblioteca Nacional renderam pesquisas sobre as designações raciais utilizadas no Brasil colonial, mas certamente Aluísio se valeu da memória (individual e coletiva) acerca dos modos de pensar as relações raciais nas décadas anteriores à escrita do romance.

A semântica colonial do conceito de raça é exposta pelo literato através da personagem Maria Bárbara, avó de Ana Rosa e sogra de Manuel Pescada, tio paterno do protagonista do livro. Segundo Aluísio Azevedo,

Maria Bárbara tinha o verdadeiro tipo das velhas maranhenses criadas na fazenda. Tratava muito dos avôs, quase todos portugueses; muito orgulhosa; muito cheia de escrúpulos de sangue. Quando falava nos pretos dizia "Os sujos" e quando se referia a um mulato dizia "O cabra" (AZEVEDO, 1975, p. 5).

Em fins do período colonial, quando supostamente teria nascido Maria Bárbara, senhora de "formação colonial", o fruto do intercurso sexual entre branco e preto era designado, principalmente, por meio de duas categorias: "mulato" e "pardo". ${ }^{29}$ Uma terceira categoria, "cabra", era invocada eventualmente. ${ }^{30}$ Porém, cabra referia-se, mais precisamente, aos filhos de uniões entre negros e mulatos. ${ }^{31}$

Os termos referidos acima eram polissêmicos. Poderiam atrelar-se à mestiçagem e/ou à condição social. ${ }^{32}$ Os dicionaristas Raphael Bluteau e Moraes e Silva assinalaram que mulato, pardo e cabra aludiam ao "homem híbrido", "filho de pai e mãe de diferentes nações" (BLUTEAU, 1712, p. 265, 628; SILVA, 1813, p. 327, 398). Pesquisas atuais sobre a segunda metade do século XVIII, no entanto, têm demonstrado que mulato, pardo e cabra denotavam também tipos sociais específicos. ${ }^{33} \mathrm{Em}$ linhas gerais, mulato e cabra eram termos pejorativos, que se ligavam à "imperfeitabilidade física e moral" e à "inconstância de costumes" dos mestiços de negro com branco (BOXER, 1967, p. 148-149; SCHWARTZ, 1996, p. 9-27; PRECIOSO, 2011, p. 51, 69). Não raro, as elites governantes acusavam os mulatos forros de serem "vadios" e "insolentes", sobretudo quando herdavam cabedais de seus pais. ${ }^{34}$ Já o termo pardo aludia a um tipo social

\footnotetext{
${ }^{29}$ Sobre as expressões e as terminologias utilizadas para se referir ao fruto do intercurso sexual entre homens brancos e mulheres negras na América portuguesa durante o século XVIII, cf. Daniel Precioso (2010, p. 27).

${ }^{30}$ Doravante, esses termos apareceram sem aspas.

${ }^{31}$ Segundo Moraes e Silva (1813, p. 314), a palavra cabra designava "o filho de pai mulato, e mãe preta, ou às avessas". "Na realidade, porém, confundia-se com 'mestiço', 'mulato' e 'pardo'” (FARIA, 1998, p. 161).

${ }^{32}$ É certo que todas se referiam igualmente à cor resultante da mistura entre branco e preto, porém, em determinados usos de linguagem, a sua carga semântica poderia se desprender da pigmentação da tez (PRECIOSO, 2010, p. 27).

${ }^{33}$ Refiro-me à vertente analítica dos vocábulos classificatórios que é tributária das formulações de Peter Eisenberg, que notou que as categorias mulato e pardo poderiam estar relacionadas à condição legal de livre com ascendência africana, e que concebem a "cor" como condição social (Cf. EISENBERG, 1989, p. 269-270; MATTOS, 1998, p. 29-30; MATTOS, 2000, p. 6-18; FARIA, 1998, p. 135; VIANA, 2007, p. 210-211; FERREIRA, 2005, p. 78; MACHADO, 2006, p. 25).

${ }^{34}$ Geralmente, os mulatos eram filhos de homens brancos, portugueses ou luso-brasileiros, que viviam amasiados com mulheres de cor, pretas, crioulas, mulatas ou cabras. Sobre a "ideologia da vadiagem", Cf., entre outros, Laura de Mello e Souza (1985).
} 
positivo, trabalhador, temente a Deus, contribuinte com os serviços da monarquia, numa palavra, integrado (RUSSELL-WOOD, 2005, p. 49).

No século XVIII, os termos "branco", "preto", "crioulo" e "pardo" foram institucionalizados pelas autoridades coloniais. As irmandades e as milícias, por exemplo, redutos corporativos das diferentes "castas de gentes", aglutinavam nas suas fileiras os indivíduos com base nessas categorias sociorraciais. Como observou Hebe Mattos, a partir da década de 1820, aproximadamente, essas categorias desaparecem dos registros oficiais, apesar de continuarem sendo usadas no cotidiano das pessoas (MATTOS, 1998). Na segunda metade do século XIX, a influência do racismo científico, que serviu como um novo dispositivo discriminador da população de cor egressa do cativeiro, atuou de molde a reabilitar essas categorias sociorraciais. O conceito de raça, obviamente, também foi trazido à baila, embora com sentidos nem sempre condizentes com os existentes no contexto colonial. ${ }^{35}$

Durante o período colonial, a Coroa portuguesa discriminava os seus vassalos através de diferentes categorias. Em princípio, as terminologias eram de matiz religioso, sendo os mouros e os judeus os indivíduos considerados de "sangue" ou "raça infecta". Com a expansão ultramarina e o surgimento de novos tipos humanos e sociais, mulatos, cafuzos, carijós, cabras, negros e pretos foram incluídos no rol dos "impuros de sangue" (VIANA, 2007, p. 53-54). Os indivíduos de "raças infectas" não podiam ocupar as principais funções da sociedade colonial, sendo vedada aos mulatos a ocupação de cargos nas Câmaras Municipais e o ingresso nas Misericórdias e em Ordens Terceiras, principais redutos do ideal de branquidade. ${ }^{36}$

Certamente, o estigma da impureza incidia mais intensamente sobre os mulatos. Como aventou Raimundo Pessoa, a causa para tanto pode ser buscada no mimo paterno através da alforria à pia de filhos havidos com negras ou mulatas cativas. ${ }^{37} \mathrm{O}$ discurso oficial elegia a vadiagem, o ócio e a insolência como os principais atributos dos mulatos, que os tornava ainda mais odiosos que os escravos, pois tinham prerrogativas de brancos e fugiam ao trabalho. Eram, em suma, considerados a mais vil "casta de gente" que habitava a América portuguesa. Não surpreende, portanto, o fato de que os mulatos consistam nos sujeitos pior adjetivados da literatura brasileira anterior ao século $\mathrm{XX}{ }^{38}$

\footnotetext{
${ }^{35}$ No entanto, embora a moderna noção de raça seja uma construção do pensamento científico europeu e norte-americano do século XIX, em meados do século XVIII, "[...] alguns autores como Buffon e De Pawn, referindo-se à 'infantilidade do continente americano' ou à 'degeneração americana', respectivamente, anteciparam alguns dos pilares que embasariam as futuras teorias sobre as desigualdades raciais, ao considerarem a existência de heranças físicas que diferenciavam permanentemente os grupos humanos" (VAINFAS, 2002, p. 616). Opunham-se, assim, ao individualismo universalista do pensamento ilustrado de um Rosseau, por exemplo.

${ }^{36} \mathrm{O}$ "mulatismo em quatro graus", isto é, até a quarta geração de antepassados, inabilitava os candidatos à ocupação de cargos camarários e ao ingresso em Misericórdias e Ordens Terceiras (BOXER, 1967, p. 150; PRECIOSO, 2010, p. 74).

${ }^{37}$ Segundo Raimundo Pessoa (2007, p. 54), a alforria a pia de filhos mulatos nascidos de ventre escravo contrariava a máxima do "parto segue o ventre", o que gerava grande animosidade na população em geral. ${ }^{38}$ É preciso ressalvar, contudo, que, em relação à mulata, desde os versos trovadorescos de Gregório de Mattos Guerra, a sensualidade de sua figura é exaltada, apesar da referência à sua permissividade também ter aflorado recorrentemente nas falas coloniais. Durante o século XIX, os atributos do "cidadão mulato" continuaram a ser de ordem negativa (LIMA, 2003, p. 51-67).
} 
Embora as definições sugeridas acima para as palavras mulato, pardo e cabra sejam um tanto artificiais e, mesmo, reducionistas, em vista da complexidade e do caráter local das nomenclaturas "raciais" no período colonial e imperial, podemos afirmar que a preferência da personagem Maria Bárbara pela qualificação dos mulatos como cabras é sintomática. Na medida em que define a avó de Ana Rosa como uma senhora "de formação colonial", Aluísio Azevedo assinala a recorrência de cargas semânticas seculares em termos "raciais" presentes nas falas do Maranhão de meados do Oitocentos. Vale notar que o termo pardo não aparece uma única vez sequer no romance de Aluísio. Aventamos duas hipóteses para tanto: o termo caiu em desuso com a ocorrência do fenômeno que Hebe Mattos qualificou de "silêncio da cor" ou, na medida em que Aluísio pretendia ressalta o "preconceito de cor" da sociedade maranhense, teria preferido o uso dos termos mulato e cabra. ${ }^{39}$ Invariavelmente, 0 termo cabra aparece como uma desqualificação social e jurídica de mulatos e, em geral, de indivíduos de ascendência africana. ${ }^{40}$ Já o termo mulato, além dessa mesma característica, por vezes, indicava tão-somente o tipo híbrido de branco e preto. Nesse sentido, a categoria se aproximava do discurso científico da época, já que tinha conotação biológica.

É preciso lembrar que Raimundo, o protagonista do romance, cresceu em Portugal, tinha a sua tez amulatada, embora seu fenótipo se aproximasse bastante do tipo humano branco, e formou-se distintamente em Direto pela Universidade de Coimbra (AZEVEDO, 1975, p. 5). Não obstante todas essas características de "embranquecimento" social e aproximação com o fenótipo branco, a sua ascendência cativa não pôde ser apagada em sua província natal. A sua "biografia" era conhecida de todos:41 a memória de seu batizado e, consequentemente, de sua alforria à pia (AZEVEDO, 1975, p. 33) ${ }^{42}$ não pôde ser apagada da mente dos maranhenses de São Luís, seus coetâneos. Portanto, apesar de bonito, distinto e letrado, era visto em sua terra natal como um "cabra cheio de fumaças", isto é, como um mulato forro e bastardo ${ }^{43} \mathrm{com}$ ares de fidalgo. Era tido, assim, perante a provinciana elite

\footnotetext{
${ }^{39} \mathrm{Na}$ página 34 aparece o termo "crioulo de Domingas" para qualificar Raimundo. O termo crioulo, na América portuguesa e no Império do Brasil, significa o escravo nascido no Brasil. Não designava, portanto, a "raça", mas o local de nascimento e a condição cativa. No entanto, a utilização do termo, tal com ocorreu acima, pode também estar associada a um significado pejorativo: no excerto acima, "crioulo" pode se referir a um indivíduo vil, não apenas em virtude da ascendência negra, mas principalmente pela ligação com a escravidão.

${ }^{40}$ Contamos nada mais do que 24 ocorrências do termo (Cf. AZEVEDO, 1975, p. 5, 18, 88, 89, 98, 99, $141,145,146,147,193,195,198,229,230,234,252,253,255)$. A designação admitia a corruptela "cabrocha", igualmente pejorativa (Cf. AZEVEDO, 1975, p. 86). O caráter racista dos xingamentos dirigidos ao mulato Raimundo poder ser observado, mais claramente, na palavra "macaquinho" (AZEVEDO, 1975, p. 47).

41 "- Até Ihe digo mais.. nem precisava cá vir, porque... continuou Diogo, abaixando a voz, ninguém aqui lhe ignora a biografia; todos sabem de quem ele saiu!" (AZEVEDO, 1975, p. 17).

${ }^{42}$ Essa modalidade de alforria era muito característica no Brasil escravista: uma escrava amasiada com um português tinha um filho, o qual ganhava a alforria no ato do batismo.

${ }^{43} \mathrm{~A}$ referência à bastardia de Raimundo aparece, entre outras ocorrências, na página 19 . No romance, a relação entre José e Domingas, sua escrava, era estável, mas não foi em nenhum momento oficializada perante a Igreja. No entanto, após ter tido Raimundo, José se casou com uma branca por nome Quitéria, que, assim como Maria Bárbara, era de "muita religião e escrúpulos de sangue" (AZEVEDO, 1975, p. 34). É com atenção à isso, que o padre Diogo afirmou que o "filho de Domingas" era um bastardo, posto que havido fora do casamento. Os filhos havidos de relações conjugais estáveis, mas
} 
maranhense, como um ser odioso e nocivo. O "doutor das dúzias", como Raimundo era frequentemente chamado no romance, não conseguiu apagar a sua origem cativa mesmo com a aquisição de um diploma de bacharel em Direito. ${ }^{44}$ Nesse sentido, a tese freyriana acerca da ascensão do bacharel mulato no Brasil Imperial deve ser balizada espacialmente, posto que em regiões provincianas, como era S. Luís, a herança de estigmas de sangue e raça, remanescentes do período colonial, atravancavam fortemente a formação de uma boa reputação por parte daqueles indivíduos.

É preciso lembrar que o narrador da trama, Aluísio Azevedo, discordava das vozes que desqualificavam Raimundo, apresentando as "qualidades" que distinguiam um "mulato bacharel" de um "mulato vadio". De acordo com o literato, Raimundo

não era um vadio, nem homem de maus instintos; aspirava ao casamento, à estabilidade; queria, no remanso de sua casa, entregar-se ao trabalho sério, tirar partido do que estudara, do que aprendera na Alemanha, na França, na Suíça e nos Estados Unidos (AZEVEDO, 1975, p. 32).

Raimundo representava - como já dissemos - o progresso, a modernidade trazida das nações avançadas do mundo. Sua desqualificação pelo "acidente da cor" (ou seja, pelo nascimento de ventre escravo) soa como um entrave moralista e atrasado à modernização do Maranhão - e da sociedade brasileira em geral. É interessante notar que Raimundo desconhecia a sua "procedência", embora a sua "história", fosse "sabida por quantos conheceram os seus parentes no Maranhão" (AZEVEDO, 1975, p. 31, 33, 48). ${ }^{45}$ Assim, diferente do que ocorria no Rio de Janeiro e em Coimbra, lugares em que a "fama pública" de Raimundo não era manchada, no Maranhão, a reminiscência de sua história familiar havia deixado uma marca indelével de sua origem escrava. O provincianismo religioso e o consequente preconceito racial, entranhados no meio social maranhense, também contribuíam para barrar a integração do doutor mulato.

Foram verificadas apenas seis ocorrências do conceito de "raça" em todo o romance - não obstante a racialização seja percebida em diversos trechos por meio do emprego de categorias sociorraciais e do discurso racista, que examinamos anteriormente. Uma das ocorrências da "raça" não será analisada pelo fato de ter sido usada como sinônimo de corja ou tipo de gente. ${ }^{46}$ Excetuando-se esse caso, as demais ocorrências de "raça" possuem sentido biológico, conforme a conotação adquirida pelo conceito no século XIX, ou de "linhagem" ou "geração", na acepção colonial do termo.

não oficializadas pela Igreja, eram chamados de "naturais". Não raro, um indivíduo se autoqualificava como "natural", mas era (des)qualificado por outros como "bastardo" ou "ilegítimo". Tratava-se de uma luta pela afirmação de uma origem pura ou espúria.

${ }^{44} \mathrm{Na}$ óptica do padre Diogo, o algoz do romance, "o governo devia até tomar uma medida séria a este respeito! devia proibir aos cabras certos misteres!" E continuava: "Deviam ser burros! burros! que só prestassem mesmo para nos servir! Malditos!" (AZEVEDO, 1975, p. 18).

${ }^{45}$ Ana Rosa também desconhecia a "biografia" de Raimundo (AZEVEDO, 1975, p. 74).

46 "Ah! amaldiçoada fosse aquela maldita raça de contrabandistas que introduziu o africano no Brasil! Maldita! mi! vezes maldita!" (AZEVEDO, 1975, p. 201, grifo nosso). 
As aparições do conceito de "raça" se deram em conversações ocorridas entre personagens coadjuvantes, ao comentarem a figura do mulato Raimundo, ou pelo próprio protagonista do romance, após tomar conhecimento da sua filiação materna.

Em uma reunião ocorrida na casa do personagem Manuel Pescada, José Roberto, senhor de engenho de cana, afirmou que

\begin{abstract}
Não cochilava com os seus escravos. Na roga era temido até pelo feitor, um pouco devoto e cheio de escrúpulos de raça. [...] Preto é preto; branco é branco! Moleque é moleque, menino é menino!" E estava sempre a repetir que o Brasil teria ganho muito, se perdesse a Guerra dos Guararapes (AZEVEDO, 1975, p. 61, grifo nosso).
\end{abstract}

Os tais "escrúpulos de raça" dizem respeito ao ideal de "pureza de sangue", ou seja, à manutenção do sangue branco na linhagem familiar. Essa acepção do termo "raça" também apareceu, ainda que implicitamente, nas falas de Maria Bárbara e Quitéria, conforme já observado. A ênfase nos lugares específicos de pretos e brancos também denota a afiliação do personagem à hierarquização social do período colonial. Subentende-se, ainda, que José preferia a colonização holandesa à portuguesa, já que lamentava a expulsão dos batavos do Recife Seiscentista com a Guerra dos Guararapes. Por trás dessa afirmação encontra-se a concepção de que os portugueses eram mais "frouxos" que os holandeses em se tratando de manter as hierarquias rígidas e de subjugar as populações mancípias.

Um diálogo entre Brito e Bento, dois personagens coadjuvantes do romance que avistaram Raimundo em um passeio público, sugere outros significados para o conceito de raça. Depois de confidenciar a Bento que o transeunte observado era um mulato, Brito teceu o seguinte juízo a respeito da "raça mulata": "São assim estes pomadas cá da terra dos papagaios! E ainda se zangam quando queremos limpar Ihes a raça, sem cobrar nada por isso! - Branquinho nacional!" (AZEVEDO, 1975, p. 82, grifo nosso). Logo, na óptica de Brito, os mulatos, além de serem "pomadas", isto é, "vaidosos" ou "presunçosos", não se contentavam com a qualificação "branquinhos nacionais", que ironicamente serviria como uma "limpeza de raça". A virulência da crítica de Brito transparece o desprezo com que os homens brancos viam os mulatos, mesmo quando não fechavam no arquétipo de "vadio" e gozavam de prerrogativas. Os mulatos, em geral, eram, portanto, na visão de Brito, "gente sem vergonha".

As demais aparições do termo "raça" têm notada acepção biológica. Raimundo, ao se dar conta da sua origem cativa e mulata, compreendeu

[...] a frieza de certas famílias a quem visitara; a conversa cortada no momento em que se aproximava; as reticências dos que Ihe falavam sobre os seus antepassados; a reserva e a cautela dos que, em sua presença, discutiam questões de raça e de sangue; a razão pela qual $D$. Amância lhe oferecera um espelho e lhe dissera: "Ora mire-se!" (AZEVEDO, 1975, p. 179180, grifo nosso).

As questões de raça, no dizer do protagonista do romance, dizem respeito à sua origem mulata, ou seja, à sua ascendência materna negra. A ofensa de $D$. Amância, ordenando-lhe que se fitasse em um espelho, denota claramente que o 
aspecto fisiológico ou biológico foi o elemento utilizado para classificar Raimundo como um mulato. Posto que esses traços fenotípicos da mulatice não eram evidentes em Raimundo, também se vislumbra aí um preconceito ligado ao seu passado escravo. Como conjeturou Raimundo, a palavra mulato continha em si um cruel destino: na "terra miserável" onde havia nascido, em virtude de sua mãe e dele próprio terem sido escravos, restava-Ihe a alternativa de amar uma "negra da sua laia" (AZEVEDO, 1975, p. 180). ${ }^{47}$ Como aventou Freyre, o "preconceito" que recaía sobre o mulato Raimundo não era de cor, sobretudo, mas de condição legal - já que ele era um liberto ou forro. Adicionaríamos, contudo, à hipótese de Freyre, a constatação de que, não obstante a herança escrava tenha sido a principal origem do preconceito contra Raimundo, a racialização de seus atributos também é denunciada por Aluísio Azevedo, embora essa acepção racial das designações tenha sido mais verossímil com o período de publicação do livro (1881) do que com o período em que se desenrolou a trama do romance (c.1850).

Outra conjectura de Raimundo ajuda a entender a acepção biológica do termo raça, tal como empregado por Aluísio Azevedo. Estonteado pela descoberta de seu passado escravo e de sua mulatice, o personagem Raimundo

[...] parou defronte do espelho e mirou-se com muita atenção, procurando descobrir no seu rosto descorado alguma coisa, algum sinal, que denunciasse a raça negra. Observou-se bem, afastando o cabelo das fontes; esticando a pele das faces, examinando as ventas e revistando os dentes; acabou por atirar com o espelho sobre a cômoda, possuído de um tédio imenso e sem fundo (AZEVEDO, 1975, p. 185, grifo nosso).

Essa procura por "sinais" da "raça negra" demonstra, claramente, que Raimundo buscou alguma evidência de sua mulatice no âmbito fenotípico. Assim, à luz do protagonista e do escritor do romance, eram as características físicas que forneciam a evidência da origem mestiça.

Concluindo, as duas últimas aparições do termo "raça" vieram em comentários de moradores de São Luís sobre a saída de Raimundo da casa de Manuel. Num deles, relata Aluísio, vieram à tona "fatos conhecidos à respeito do preconceito de cor" sofrido por "celebridades de raça escura", bem como referências aos talentos e à esperteza das "raças cruzadas" (AZEVEDO, 1975, p. 194-195, grifo nosso). A complementação "escura" à palavra "raça" denota, claramente, a sua acepção racialista, já que remete à cor. De modo semelhante, a expressão "raças cruzadas" refere-se à mestiçagem biológica.

\footnotetext{
${ }^{47}$ Os significados dos vocábulos "preta" e "negra" parecem ser, em vários momentos do romance, intercambiáveis, não obstante guardem certas particularidades. "Negro", às vezes, atrelava-se a cor, mas também poderia se referir à condição legal de cativo (AZEVEDO, 1975, p. 18). "Preto" também foi usado como designação da cor, mas, na maioria das ocorrências, dizia respeito à condição jurídica de escravo (AZEVEDO, 1975, p. 56, 37 e 57).
} 


\section{Palavras finais}

Procuramos demonstrar que a atividade de caricaturista se entremeou à de escritor em Aluísio Azevedo. No romance $O$ mulato, como nas charges que Aluísio havia publicado em periódicos cariocas, as personagens são caricatas. Podemos enxergar, ainda, o recurso a alegorias para representar o atraso da província do Maranhão e os entraves para a sua modernização.

Mais importante em nossa análise, porém, foi a historicização do romance, tanto do ponto de vista da contextualização da sua produção - resgatando a sua relação com a atividade de cronista que Aluísio exercia n'O Pensador - como nas perspectivas históricas e sociológicas intrínsecas à narrativa romanesca d'O mulato. Constatamos que, assim como ocorria na linha editorial d'O Pensador, Aluísio rejeitava os determinismos raciais - tais como presentes em outros intelectuais brasileiros dos anos 1880 e 1890, como Nina Rodrigues -, adotando a perspectiva dos determinismos do meio.

Neste sentido, a mestiçagem não aparece como sinônimo de degeneração moral e biológica. Embora críticos literários como Josué Montello relacionem a constituição física do mulato Raimundo a resquícios do romantismo, parece mais factível a linha de interpretação de Gilberto Freyre em Sobrados e mucambos. Mas não a corroboramos totalmente: não parece plausível que o protagonista tenha sido "copiado do real", como sugeriu o escritor pernambucano. Parece-nos, antes, que a eugenia do protagonista do romance se relaciona com a refutação das teses de degeneração dos mulatos. A própria trajetória de Raimundo, ex-escravo que se forma bacharel em Direito pela Universidade de Coimbra, demonstra que a ascendência africana não era um impedimento para o desenvolvimento intelectual e para a formação de homens modernos.

No romance, o preconceito de cor aparece como um traço do atraso brasileiro e é atributo de homens da Igreja e dos católicos mais velhos, ainda de "formação colonial". Um dos aspectos mais radicais do romance foi vestir a carapuça da modernidade em um mulato, verdadeira afronta à sociedade escravista da época. De qualquer modo, ainda que o livro - do ponto de vista do narrador - não represente a mestiçagem de modo negativo, o modo como os negros são representados - sobretudo, a escrava Domingas, mãe do mulato - aponta uma visão pejorativa do negro. A construção do protagonista mulato do romance com traços quase europeus sugere ainda que, para Aluísio, quanto mais próximo do fenótipo branco, mais bem vindos seriam os mestiços para a constituição de uma nação moderna.

Constatamos também que os personagens mais importantes do romance encarnam determinados arquétipos, formando uma alegoria do passado e do presente (época de Aluísio) do Brasil. O atraso e a fonte de todos os vícios da sociedade são personificados no padre Diogo, ou seja, na Igreja Católica. A figura do caixeiro Dias encarna o arquétipo do português, também identificado a algo atrasado, colonial. $O$ progresso, a modernidade e o cientificismo, como já mencionado, se materializam na figura do mulato. Tendo em vista o determinismo do meio, provinciano no caso de São Luís, essa figura moderna veio de fora, da Europa. O fatalismo do romance, fruto do preconceito de cor e provincianismo maranhense, acaba por vencer a modernidade: o mulato é morto pelo caixeiro Dias, que se casa com Ana Rosa, com as bênçãos do padre Diogo. 
Por fim, as designações sociorraciais presentes no romance sugerem a realização de uma pesquisa histórica por parte de Aluísio. Não fortuitamente, o termo "cabra" foi utilizado recorrentemente como um termo depreciativo para se referir ao mulato protagonista. O uso mais frequente do termo "raça" sugere uma acepção oitocentista, já que estava relacionado à biologia - e não à linhagem, como na época colonial. O emprego da expressão "pureza de sangue" - no contexto da defesa da branquidade - também remonta ao vocabulário colonial. Curiosamente, o termo pardo, utilizado de forma mais recorrente para se referir ao mulato integrado e trabalhador, não foi utilizado por Aluísio para intitular o seu romance. Como o termo "mulato" era sinônimo de mestiço - diferente de "pardo", que além de mestiço, designava o livre não-branco integrado socialmente -, a escolha desse termo para intitular o romance reforça a tese de que Aluísio se posicionava favoravelmente à mestiçagem.

\section{REFERÊNCIAS}

ALBUQUERQUE, Wlamyra. A vala comum da "raça emancipada": abolição e racialização no Brasil, breve comentário. História Social, n. 19, p. 91-108, 2010.

ALONSO, Angela. Ideias em movimento: a geração de 1870 na crise do Brasil-Império. São Paulo: Paz e Terra, 2002.

ARAÚJO, Ricardo Benzaquen de. Guerra e paz: Casa-Grande \& Senzala e a obra de Gilberto Freyre nos anos 30. Rio de Janeiro: Editora 34, 1994.

AZEVEDO, Aluísio. O mulato. São Paulo: Martins; Brasília: INL, 1975.

AZEVEDO, Célia Maria Marinho de. A recusa da "raça": anti-racismo e cidadania no Brasil dos anos 1830. Horizontes Antropológicos, Porto Alegre, ano 11, n. 24, p. 297320, jul./dez. 2005.

BLUTEAU, D. Rapahel. Vocabulario portuguez e latino. Coimbra: Collegio das Artes da Companhia de Jesus, 1712.

BOXER, Charles R. Relações raciais no império colonial português, 1415-1825. Rio de Janeiro: Tempo Brasileiro, 1967.

BURKE, Peter. Gilberto Freyre e a nova história. Tempo Social, São Paulo, n. 9, v. 2, p. 1-12, outubro de 1997.

CADEMARTORI, Ligia. Obra traz dispensável tom narcisista: A História Contada, coletânea organizada por Sidney Chalhoub e Leonardo Affonso Pereira, cai na tentação de confundir literatura com testemunho histórico. Correio Brasiliense, 30 de agosto de 1998.

CANO, Jefferson. O fardo dos homens de letras: o "orbe literário" e a construção do império brasileiro. 2001. 407 f. Tese (Doutorado em História). Programa de Pós-Graduação em História, Universidade Estadual de Campinas, Campinas, 2001.

CHALHOUB, Sidney, NEVES, Margarida, PEREIRA, Leonardo (orgs.). História em cousas miúdas: capítulos de história social da crônica no Brasil. Campinas, SP: Editora da UNICAMP, 2005. 
CHALHOUB, Sidney. Machado de Assis: historiador. São Paulo: Companhia das Letras, 2003.

CHARTIER, Roger. A história cultural: entre práticas e representações. Lisboa. Difel, 1990.

CRUZ, Laura Camilo dos Santos. Edição crítica e genética do romance O Mulato, de Aluísio Azevedo. Manuscrítica, n. 11, p. 271-272 (2003).

DAMATTA, Roberto. O Brasil como morada: apresentação para Sobrados e mucambos. In: FREYRE, Gilberto. Sobrados e mucambos: a decadência do patriarcado e desenvolvimento do urbano. $16^{\mathrm{a}}$ ed. São Paulo: Global, 2006, p. 11-26.

EISENBERG, Peter. Homens esquecidos: escravos e trabalhadores livres no Brasil séc. XVIII e XIX. Campinas, SP: Ed. UNICAMP, 1989.

FANINI, Angela Maria Rubel. Os romances-folhetins de Aluísio de Azevedo: aventuras periféricas. 2003. 340 f. Tese (Doutorado em Teoria Literária). Programa de PósGraduação em Teoria Literária, Universidade Federal de Santa Catarina, Florianópolis, 2003.

FAORO, Raymundo. Machado de Assis: a pirâmide e o trapézio. São Paulo: Companhia Editora Nacional, 1974.

FARIA, Sheila de Castro. A colônia em movimento: fortuna e família no cotidiano colonial. Rio de Janeiro: Nova Fronteira, 1998.

FERREIRA, Roberto Guedes. Pardos: trabalho, família, aliança e mobilidade social. Porto Feliz, São Paulo, c. 1789 - c. 1850. 2005. 364 f. Tese (Doutorado em História). Programa de Pós-Graduação em História, Universidade Federal do Rio de Janeiro, Rio de Janeiro, 2005, 364 p.

FREYRE, Gilberto. Sobrados e mucambos: a decadência do patriarcado e desenvolvimento do urbano. São Paulo: Global, 2006.

GLEDSON, John. Machado de Assis: ficção e história. Rio de Janeiro: Paz e Terra, 1986.

JÚNIOR, Araripe. Estilo tropical: a fórmula do naturalismo brasileiro. In: BOSI, Alfredo. Araripe Júnior: teoria, crítica e história literária. Rio de Janeiro: LTC, 1978, p. 75-76.

LAVELEYE, Emílio de. O catolicismo e o protestantismo. O Pensador, edição 43, 1881.

LIMA, Ivana Stolze. Cores, marcas e falas: sentidos da mestiçagem no Império do Brasil. Rio de Janeiro: Arquivo Nacional, 2003.

MACHADO, Cacilda. A trama das vontades: negros, pardos e brancos na produção da hierarquia social (São José dos Pinhais - PR, passagem do XVIII para o XIX). 2006. 418 f. Tese (Doutorado em História). Programa de Pós-Graduação em História, Universidade Federal do Rio de Janeiro, Rio de Janeiro, 2006.

MATTOS, Hebe Maria. Das cores do silêncio: os significados da liberdade no Sudeste Escravista - Brasil, século XIX. Rio de Janeiro: Nova Fronteira, 1998.

MATTOS, Hebe Maria. Escravidão e cidadania no Brasil monárquico. Rio de Janeiro: Zahar, 2000. 
MENCARELLI, Fernando. A cena aberta: a absolvição de um bilontra e o teatro de revista de Arthur Azevedo. Campinas, SP: Editora da Unicamp, 1999.

MONTELLO, Josué. Aluísio Azevedo e a polêmica d" "O Mulato". Rio de Janeiro: J. Olympio; Brasília: INL, 1975.

PEREIRA, Astrojildo. Machado de Assis: ensaios e apontamentos avulsos. Belo Horizonte: Oficina de Livros, 1991.

PEREIRA, Leonardo Affonso de Miranda. A realidade como vocação: literatura e experiência nas últimas décadas do império. In: GRINBERG, Keila; SALLES, Ricardo (orgs.). O Brasil Imperial. Vol. I -1831-1889. Rio de Janeiro: Civilização Brasileira, 2009.

PESSOA, Raimundo. Gente sem sorte: os mulatos no Brasil colonial. 2007. 232 f. Tese (Doutorado em História). Programa de Pós-Graduação em História, Universidade Estadual Paulista, Franca, 2007.

PRECIOSO, Daniel. Legítimos vassalos: pardos livres e forros na Vila Rica colonial (1750-1803). 2010. 249 f. Dissertação (Mestrado em História). Programa de Pós-Graduação em História, Universidade Estadual Paulista, Franca, 2010.

REIS, José Carlos. As identidades do Brasil, de Varnhagen a FHC. $8^{a}$ ed. Rio de Janeiro: Editora FGV, 2006.

RODRIGUES, José Honório. Explicação: normas da $4^{a}$ edição (1954). In: ABREU, Capistrano de. Capítulos de história colonial, 1500-1800. Belo Horizonte: Itatiaia, 2000.

RUSSELL-WOOD, A. J. R. Escravos e libertos no Brasil colonial. Rio de Janeiro: Civilização Brasileira, 2005.

SCHWARCZ, Lilia Moritz. O espetáculo das raças: cientistas, instituições e questão racial no Brasil - 1870-1930. São Paulo: Companhia das Letras, 1993.

SCHWARZ, Roberto. Ao vencedor as batatas: forma literária e processo social nos inícios do romance brasileiro. São Paulo: Duas Cidades, 1981.

SCHWARZ, Roberto. Um mestre na periferia do capitalismo: Machado de Assis. São Paulo: Duas Cidades, 1990.

SCHWARTZ, Stuart B. Brazilian ethnogenesis: mestiços, mamelucos, and pardos. In: GRUZINSKI, Serge; WATCHEL, Nathan (orgs.). Le nouveaux monde, mondes nuveaux. Paris: Éditions Recherche sur les Civilisations/Éditions de l'École des Hautes Études en Sciences Sociales, 1996, p. 9-27.

SILVA, Antonio de Moraes e. Dicionário da língua portuguesa. Lisboa: Typografia Lacérdina, 1813.

SKIDMORE, Thomas E. Preto no branco: raça e nacionalidade no pensamento brasileiro. Rio de Janeiro: Paz e Terra, 1976.

SOUZA, Jessé. Uma interpretação alternativa do dilema brasileiro. In: SOUZA, Jessé. A modernização seletiva: uma reinterpretação do dilema brasileiro. Brasília: UNB, 2000 
SOUZA, Laura de Mello e. Desclassificados do ouro: a pobreza mineira no século XVIII. Rio de Janeiro: Graal, 1985.

SOUZA, Roberto Acízelo. Perspectiva científica. In: SOUZA, Roberto Acízelo. Formação da teoria da literatura. Niterói: Editora Universitária, 1987, p. 56-124.

TODOROV, Tzvetan. Nós e os outros: a reflexão francesa sobre a diversidade humana. Rio de Janeiro: Jorge Zahar, 1993.

VAINFAS, Ronaldo (org.). Dicionário do Brasil Imperial (1822-1889). Rio de Janeiro: Objetiva, 2002.

VENTURA, Roberto. "Estilo Tropical”: a natureza como pátria. Remate de Males, Campinas, vol. 7, p. 27-38, 1987.

VERÍSSIMO, José. História da literatura brasileira. Rio de Janeiro: [s.n.], 1954.

VIANA, Larissa Moreira. O idioma da mestiçagem: as irmandades de pardos na América Portuguesa. Campinas, SP: Editora da UNICAMP, 2007.

\section{NOTAS}

Daniel Precioso: Doutor. Professor Efetivo, Universidade Estadual de Goiás, Curso de História, Quirinópolis, GO, Brasil. Av. Brasil, 435, Hélio Leão II, 75860-000, Quirinópolis, GO, Brasil.

Como citar: PRECIOSO, Daniel. Raça, mestiçagem e designações sociorraciais no romance O mulato, de Aluísio Azevedo (1850-1881). Esboços, Florianópolis, v. 26, n. 41, p. 149-178, jan./abr., 2019.

\section{FINANCIAMENTO}

Não se aplica.

\section{APROVAÇÃO DE COMITÊ DE ÉTICA EM PESQUISA \\ Não se aplica.}

\section{CONFLITO DE INTERESSES}

Não se aplica.

\section{LICENÇA DE USO}

Este artigo está licenciado sob a Licença Creative Commons CC-BY Internacional 4.0. Com essa licença você pode compartilhar, adaptar, criar para qualquer fim, desde que atribua a autoria da obra.

\section{PUBLISHER}

Universidade Federal de Santa Catarina. Programa de Pós-graduação em História. Portal de Periódicos UFSC. As ideias expressadas neste artigo são de responsabilidade de seus autores, não representando, necessariamente, a opinião dos editores ou da universidade.

\section{HISTÓRICO}

Recebido em: 11 de junho de 2018

Aprovado em: 18 de outubro de 2018 